\title{
Enterprise Architecture Management: Requirements for Conception of Key Figures to Ensure Transparency and Efficiency
}

\author{
Ronja Höpfner ${ }^{1}$ and Bjarne Erik Roscher ${ }^{1,2}$ * \\ ${ }^{1}$ FOM Hochschule für Oekonomie und Management, Germany \\ ${ }^{2}$ University of Latvia, Riga, Latvia \\ *Corresponding Author: iD https://orcid.org/0000-0003-1358-4714
}

\begin{abstract}
Companies are more and more dependent on information technology (IT) and the buzzword digitization is present everywhere. Information technology needs to be managed, serviced, and supported by IT organizations to ensure business continuity. Traditionally heads of the IT departments have been fully responsible for all aspects of IT usage in the company - including IT cost, IT governance, IT \& process planning \& implementation and IT operation. The change of technology offerings by external partners, results in a need to focus on strategic tasks like strategy and roadmap planning, IT governance, IT budgeting and enterprise architecture management (EAM). This results in the fact that there is a need of more intensive Business-IT alignment to ensure that IT architecture of a company supports the business processes at its best and to ensure the economic value contribution of IT as a hole. The development of a key figure system for EAM supports responsible managers to ensure efficiency of IT.
\end{abstract}

The scope of this research in progress is, to understand the concept of Enterprise Architecture Management and Key Figures. Additionally, to explore the current state of scientific publications regarding the requirements and conception of Key Figure Systems. Purpose: The outcome will be used in future research to design a key figure system framework to enable practitioners to measure the efficiency of EAM. Methodology: This research is carried out using different methodologies of literature research and clustering techniques. Results: The literature review gives a structured overview over requirements for Key figures and their conception. Outlook: In future research an EAM Measurement framework will be designed comprising of Key Figures and their corresponding value adds.

Keywords: Enterprise Architecture Management, Key Figures, Key Performance Indicators, Chief Information Officer, Business IT Alignment

JEL code: L2, M15

\section{Internal and external influences on Organisations and how EA can help}

Due to the fourth industrial revolution, companies are in a VUCA world. VUCA describes the environmental influences of instability, uncertainty, complexity and ambiguity on the corporate world (Alaloul et al., 2020). Within a company, VUCA influences the organization, 
processes and locations as well as, from a technical point of view, the systems, data and technologies of a company (Minciu et al., 2020) (see Figure 1).

The challenge for companies is to take advantage of the new realities and to act instead of reacting in a world characterized by inconsistencies, uncertainties, complexity and ambiguities.

Figure 1: VUCA is the driver for IT Landscape and IT operation

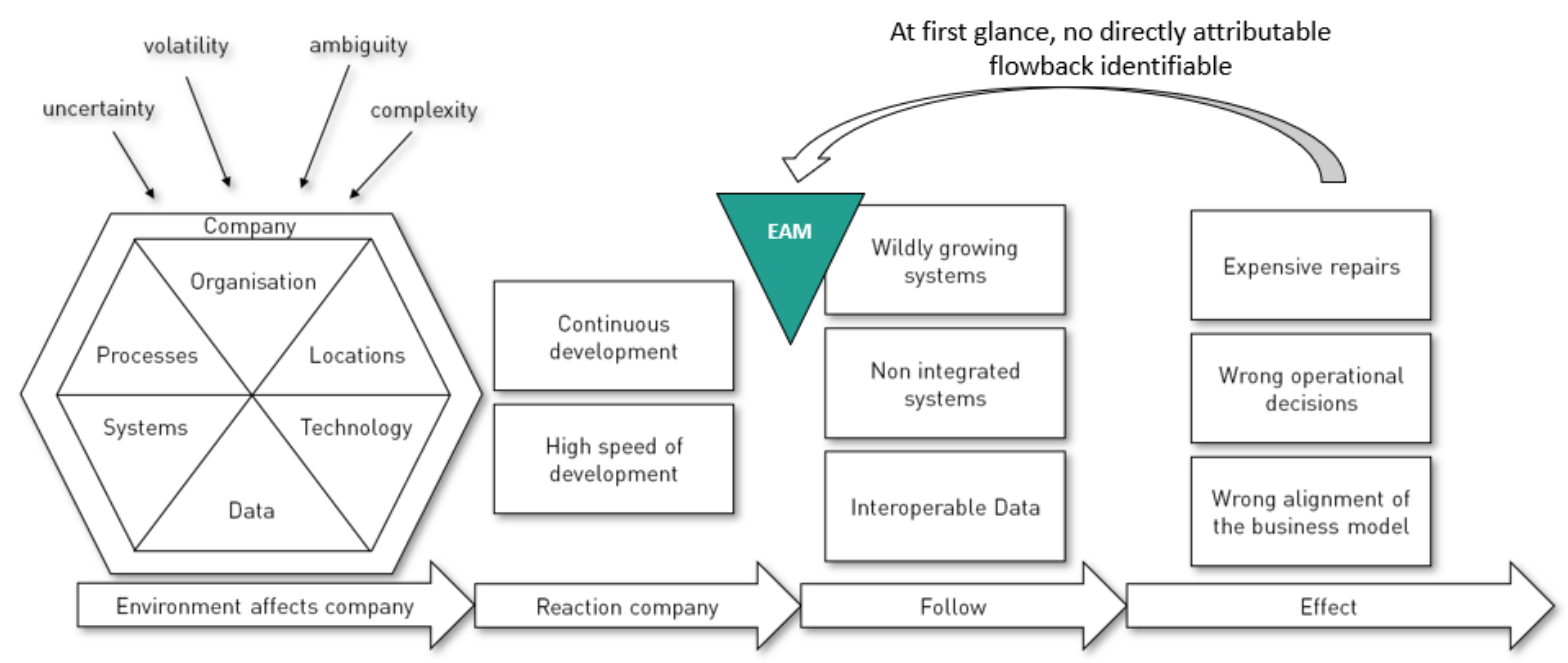

Source: own illustration

As a response to this challenge, and thus as a competitive advantage, companies see the increase in development speed and the continuous development of systems for handling ever larger amounts of data. (Bernardis et al., 2017), (Tannady et al., 2020), (Hierzer, 2017).

In addition to the expected benefits, this step can also have negative effects on the company. Rapid and continuous development can encourage a proliferation of non-integrated systems. The consequences are redundancies, inconsistencies and a different understanding of the maintained data as well as increased complexity and insufficient support of processes in a holistic view.

The effects of the mentioned consequences are expensive "repair processes". In addition, incorrect data bases lead to wrong decisions in the operative business, up to a possible wrong alignment of the business model. This has incalculable consequences that can ultimately threaten the very existence of the entire company.

In addition to the aspects mentioned and the additional challenges in the context of IT security, such as the protection of company secrets and personal data, this makes a system landscape / architecture that is controlled across all levels, but still lean and modern, essential. (Hierzer, 2017) Ensuring this in the long term is the task of effective and efficient Enterprise Architecture Management (EAM).

From an IT management point of view EAM is the operative part of the design dimensions available. IT strategy supports one side business processes and business models, yet the provision of the Enterprise Architecture supports the it on a day to day bases. Figure 2 show the necessary building blocks and the involved stakeholders in the organizations (Durst, 2007). 


\section{icalingme}

$4^{\text {th }}$ International Conference on Advanced Research in

Amsterdam, Netherlands

BUSINESS, MANAGEMENT \& ECONOMICS

16-18 July 2021

Figure 2: Design Dimensions of IT and its Stakeholders within the organization

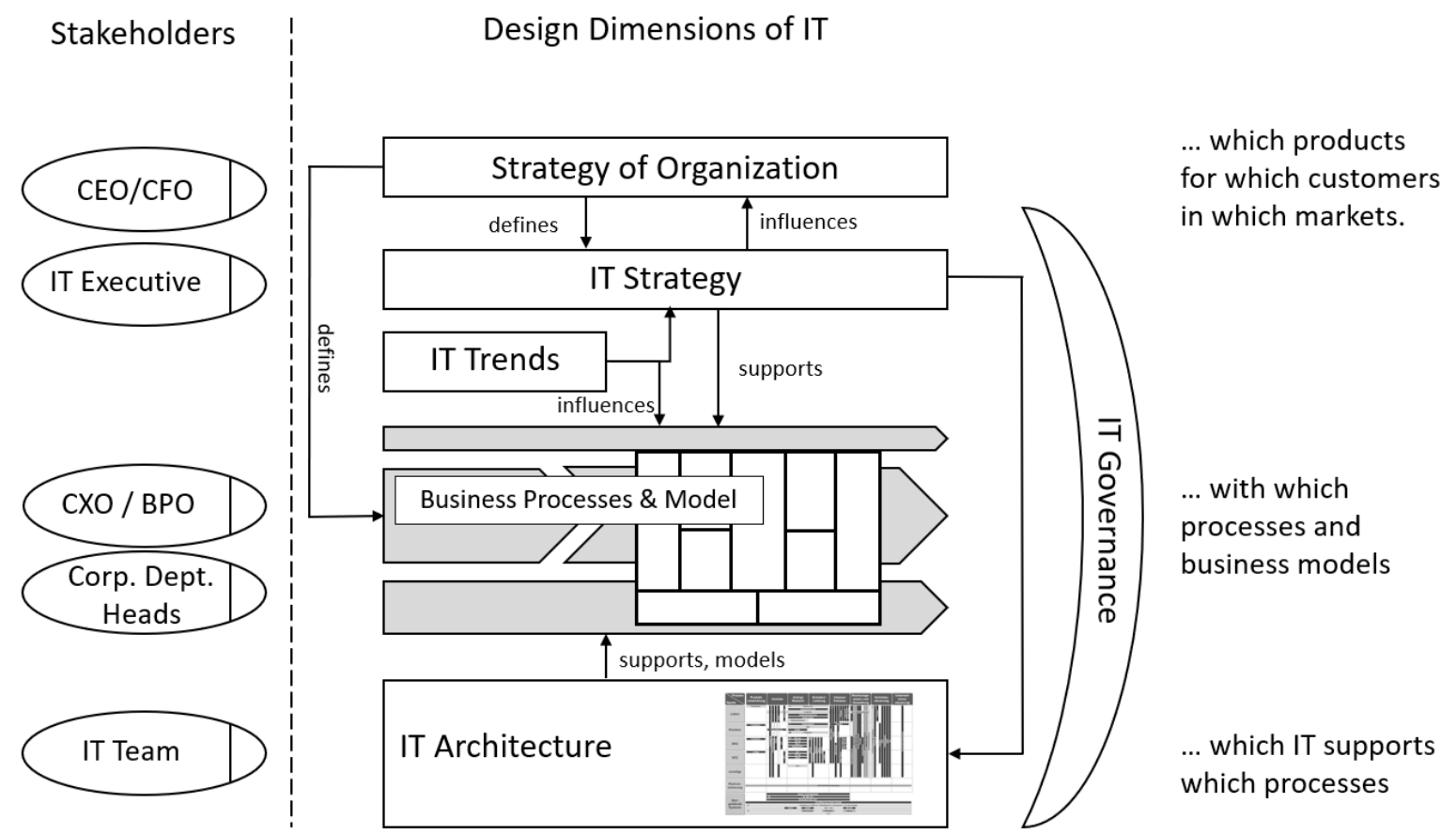

Source: author's construction based on Durst's IT design dimensions (Durst 2007)

\subsection{Problem Statement \& Research question}

EAM offers a comprehensive answer for the initial situation presented above. It shows the current use of information technologies in the company and provides a roadmap to achieve a future state. As a "hinge" between IT and business, EAM makes it possible to proactively control IT costs for development and operation and to manage the complexity of the application landscape. (Keuntje et al., 2010), (Bente et a., 2012). The problem here is that, at first glance, no direct attributable return flow can be calculated for EAM in a classic business calculation. (Durst, 2007). Business is only secured and made possible indirectly, be it by avoiding risks or taking advantage of opportunities. There is therefore no instrument to quantitatively and qualitatively evaluate and present the benefits of EAM. (see Figure 1).

Overall Research question for Research Project:

- How can the effect of enterprise architecture management on business success be quantified to demonstrate its business imperative?

In order to achieve this, this conference paper aims to answer following questions by the use of a literature analysis: 
- What are the requirements for a key figure system?

- How is a key figure system designed?

- What are the requirements for a key figure?

- How is the conception of a key figure proceeded?

\subsection{Literature review methodology}

The literature review methodologies used in this specific research are the "method of concentric circles" or the backward-looking search uses the bibliography of a central source as an entry point for a literature search. As the cited sources are of mostly older (cf. Nienhüser et al., 2003, p. 26), (cf. Kornmeier, 2018, p. 89) futher methodologies have been used, which are the "systematic search", which included electronic media, reference works, book catalogs and journal directories. The advantage was a comprehensive overview of the subject area examined. (Nienhüser et al., 2003), (Kornmeier, 2018), (Becker, 2012). Finally, the method of "forward search" was used starting at central sources and investegated which authors used this publication in its citations. The review used the Social Science Citation Index (SSCI) to cary out the search (Nienhüser et al., 2003), (Kornmeier, 2018).

\subsubsection{Clustering of information for furhter analysis}

In the progression of this research project the collected information was clustered in group sessions using the techniques of meta plan (Disselkamp, 2012), the cluster method (Rico, 2002) and the mind mapping technique.

\subsection{Enterprise Architecture \& Frameworks:}

An Enterprise Architecture (EA) is a structured representation of the company structure from an information point of view. It shows the current and future use of IT in the company from a structural and process-organizational perspective and how it is interlinked with company processes. (Bente et a., 2012), (Siepermann et al., 2018).

The Enterprise Architecture Management (EAM) is the implementation and control of the Enterprise Architecture and is according to Keuntje et al. described as follows: "EAM is a useful tool for both cost and performance-oriented management of IT. It makes it possible to proactively control IT costs for development and operation and to manage the complexity of the application landscape. "(Keuntje et al., 2010). The Chair of Computer Science at the University of Munich also supports this very IT-related definition and names the continuous and iterative process for optimizing IT as one of the core tasks of EAM. Nevertheless, EAM also takes business processes, business goals, strategies, etc. into account (Matthes et al., 2005). The German Association for Information Technology, Telecommunications and New Media (Bitkom) takes up this last aspect even more and describes EAM in its publication from a company perspective: "An Enterprise Architecture (EA) describes the interaction of business processes and IT in the company and thus represents provide a strategic, conceptual and organizational framework for the design of the IT landscape. An EA can make a significant contribution to the design and implementation of corporate goals." (Bitkom, 2011). The focus 
here is on the fact that EAM is a mediator between business and IT. Other literature sources share this view. (The Open Group, 2018), (Zachman, 1987), (Kluge, 2006).

According to Langenberg et al. (Langenberg et al, 2004) there is no established definition for EAM. This can be confirmed after an analysis of the literature, but many similarities can be found in the definitions. In particular, the key words cost and performance improvement in IT, EAM as a link between business and IT, complexity management and the design of an IT roadmap are mentioned in the various definitions. A separate definition is therefore used for this work, which contains all the important components of the EAM (see Table 1):

"Enterprise Architecture Management comprises two areas. On the one hand, from a business perspective, EAM creates transparency about the IT landscape and its influence on company processes. Therefore, an IT strategy geared towards corporate goals can be designed and the complexity of the IT landscape can be mastered. On the other hand, EAM enables the IT landscape to be designed cost-effectively and, at the same time, to be powerful. "

Table 1: Definition of EAM - results from literature review

\begin{tabular}{|c|c|c|c|c|c|c|c|}
\hline \multirow[b]{2}{*}{ Definition of EAM } & \multicolumn{7}{|c|}{ Literature Soruce } \\
\hline & 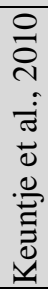 & 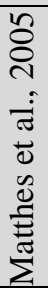 & 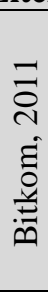 & 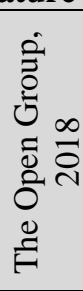 & $\begin{array}{l}\text { o } \\
\text { } \\
\tilde{\Xi} \\
\tilde{\Xi} \\
\frac{\Xi}{\tilde{J}} \\
\text { N }\end{array}$ & 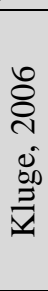 & 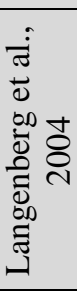 \\
\hline EAM creates transparency about the IT Landscape & & & $\mathrm{x}$ & $\mathrm{x}$ & $\mathrm{x}$ & $\mathrm{x}$ & $\mathrm{x}$ \\
\hline EAM visualizes the IT influence on business processes & & $\mathrm{x}$ & $\mathrm{x}$ & $\mathrm{x}$ & $\mathrm{x}$ & $\mathrm{x}$ & $\mathrm{x}$ \\
\hline EAM models a target-oriented IT strategy & $\mathrm{x}$ & & & & $\mathrm{x}$ & & $\mathrm{x}$ \\
\hline EAM supports to maintain a complex IT landscape & $\mathrm{x}$ & $\mathrm{x}$ & & $\mathrm{x}$ & $\mathrm{x}$ & & \\
\hline EAM reduces IT cost & $\mathrm{x}$ & $\mathrm{x}$ & & & & & \\
\hline EAM enables a powerful IT landscape & $\mathrm{X}$ & $\mathrm{X}$ & & & & & \\
\hline
\end{tabular}

Source: own literature analysis

\subsection{Definition of EAM Key Figure Systems}

"The primary goal of strategic corporate management is to secure the company's long-term existence. For this purpose, long-term and forward-looking planning must be carried out and the expected future developments in the environment influencing the company must be considered.

Key figure systems support this. The term "key figure system" is not defined uniformly in the literature. Nevertheless, the same four characteristics that make up a key figure system are repeatedly mentioned in large number of definitions. These are shown in Table 2. 
Table 2: Definition of Key Figures in Literature - results from literature review

\begin{tabular}{|c|c|c|c|c|}
\hline \multirow[b]{2}{*}{ Definition of Key Figures } & \multicolumn{4}{|c|}{ Definition } \\
\hline & $\begin{array}{l}\text { Key figure systems } \\
\text { as the linking and } \\
\text { connection of key } \\
\text { figures }\end{array}$ & $\begin{array}{l}\text { Key figure systems } \\
\text { as a transparent } \\
\text { representation of } \\
\text { company } \\
\text { performance using } \\
\text { monetary and non- } \\
\text { monetary key } \\
\text { figures }\end{array}$ & $\begin{array}{l}\text { Key figure systems } \\
\text { as a basis for } \\
\text { decision-making }\end{array}$ & $\begin{array}{l}\text { Key figure systems } \\
\text { as a safeguard for } \\
\text { the implementation } \\
\text { of the corporate } \\
\text { strategy }\end{array}$ \\
\hline Neely A. et al., 1995 & & $\mathrm{x}$ & & \\
\hline Mathur A. et al., 2011 & & $\mathrm{x}$ & & $\mathrm{x}$ \\
\hline Kleindienst B., 2017 & & $\mathrm{x}$ & & $\mathrm{x}$ \\
\hline Ossola-Haring C. et al., 2016 & $\mathrm{x}$ & $\mathrm{x}$ & & \\
\hline Brunner J., 1999 & & $\mathrm{x}$ & & $\mathrm{x}$ \\
\hline Bourne M. et al., 2000 & & $\mathrm{x}$ & & $\mathrm{x}$ \\
\hline Garengo P. et al., 2005 & & $\mathrm{x}$ & $\mathrm{x}$ & \\
\hline Chalmeta R. et al., 2012 & & $\mathrm{x}$ & $\mathrm{x}$ & \\
\hline Wettstein T., 2001 & & $\mathrm{x}$ & $\mathrm{x}$ & \\
\hline Brecht U., 2005 & $\mathrm{x}$ & $\mathrm{x}$ & & \\
\hline Bititci U. et al., 1997 & & $\mathrm{x}$ & & \\
\hline Gladen W., 2014 & $\mathrm{x}$ & $\mathrm{x}$ & & \\
\hline
\end{tabular}

Source: own literature analysis

\subsection{Definition of key figure}

As described above, key figures form the basis of the key figure system and enable the company to be planned and controlled. Basically, the task of key figures is to quantify facts and to present information or measured variables in aggregated form. This is made possible by the fact that key figures are quantitative information that is prepared for the specific needs of company analysis and control. (Ossola-Haring et al., 2016), (Gladen, 2014), (Kleindienst, 2017), (Weber, 1999).

On closer inspection, key figures can be distinguished with regard to their type of calculation, i.e. whether it is an absolute or relative key figure (ratio key figure). In addition, they can be further structured according to content criteria for a better overview. (Ossola-Haring et al., 2016).

In addition to the term "key figure", there are also so-called "indicators", which are often used in the literature as a synonym for the key figure. It is important to distinguish between these. Indicators are not condensed information, but substitute values that give tendencies towards the development of a performance level enable. They are also not self-explanatory and require interpretation. (Weber, 1999), (Gladen, 2014).

This distinction will be retained for the further course of the work, because indicators should be largely dispensed with in the interests of a comprehensible and interpretation-free system of indicators. 
A special definition must be made for key performance indicators (KPIs). KPIs are used when it comes to measuring objectives within the company. A KPI shows the degree of fulfillment of certain objectives or the deviation from the respective target value. A key figure, on the other hand, is a measurable value. (Richert, 2006).

\section{Design of EAM Key Figures}

\subsection{Requirements for Key Figures}

As with the key figure systems, there are also requirements for the individual key figure to ensure that it is meaningful and correct. The literature agrees (see Table 3) that the key figure specified for this should be easy to understand and as free of interpretation as possible. In addition, it must be clear where the key figure gets its basic data for calculation and how the calculation is carried out. Both Neely and Mathur and Ossola-Haring et al. think it is important that the key figure is derived from the company's strategy. Further aspects that are occasionally mentioned by sources to increase the informative value of the key figure is the definition of a target value and a time interval in which the key figure is checked for changes and the necessary measures are derived. Chalmeta et al. finally, thinks it is important to appoint a person responsible for the key figure who monitors the key figure continuously, i.e. not at time intervals, and who ensures the implementation of the defined measures. (Chalmeta et al., 2012), (Brecht, 2012), (Ossola-Haring et al., 2016), (Mathur et al., 2011), (Neely et al., 1995).

Table 3: Requirements for Key Figures - results from literature review

\begin{tabular}{|c|c|c|c|c|c|}
\hline \multirow[b]{2}{*}{ Requirements for Key Figures } & \multicolumn{5}{|c|}{ Literature Source } \\
\hline & 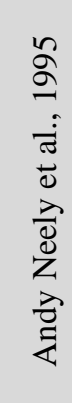 & 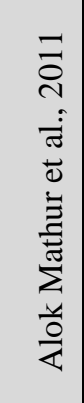 & 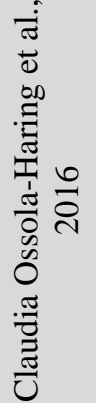 & 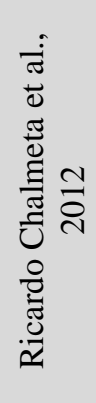 & 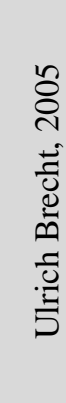 \\
\hline Freedom of interpretation of the key figure & $\mathrm{x}$ & $\mathrm{x}$ & $\mathrm{X}$ & $\mathrm{x}$ & $\mathrm{x}$ \\
\hline Clear data reference & & $\mathrm{x}$ & $\mathrm{X}$ & $\mathrm{x}$ & \\
\hline Defined calculation method & & $\mathrm{x}$ & & $\mathrm{x}$ & \\
\hline Relation to strategy & & & $\mathrm{x}$ & $\mathrm{x}$ & \\
\hline Defined target value & $\mathrm{x}$ & $\mathrm{x}$ & $\mathrm{x}$ & $\mathrm{x}$ & $\mathrm{x}$ \\
\hline Fixed time interval & & $\mathrm{x}$ & $\mathrm{x}$ & $\mathrm{x}$ & \\
\hline Definition of a person responsible for key figures & & $\mathrm{x}$ & $\mathrm{X}$ & $\mathrm{x}$ & $\mathrm{x}$ \\
\hline
\end{tabular}

Source: own literature analysis 


\subsection{Conception of Key Figure Systems}

Several procedural models can be found in the literature for developing a key figure system. These are structured identically in the key points, but still show differences in individual design steps (see Table 4).

According to the literature, the key steps in setting up a key figure system are, in addition to project planning, the definition of company goals, the definition of the key figure areas at the strategic level, the implementation and validation of the previously defined key figures and finally the continuous improvement of these steps. (Chalmeta et al., 2012), (Brecht, 2012). (Möller et al., 2015), (Neely et al., 2002).

Table 4: Conception of a Key Figure System - results from Literature review

\begin{tabular}{|c|c|c|c|c|c|c|}
\hline \multirow[b]{2}{*}{ Conception of a Key Figure System } & \multicolumn{6}{|c|}{ Literature Source } \\
\hline & 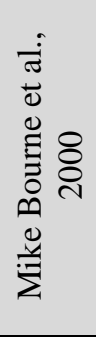 & 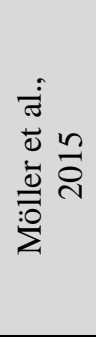 & 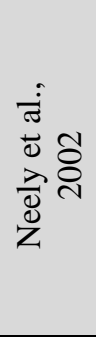 & 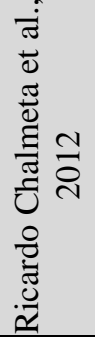 & 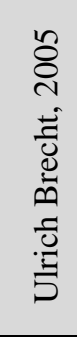 & 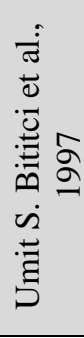 \\
\hline Project planning & & $\mathrm{x}$ & $\mathrm{x}$ & $\mathrm{x}$ & & \\
\hline Definition of corporate goals & & $\mathrm{x}$ & $\mathrm{x}$ & $\mathrm{x}$ & $\mathrm{x}$ & $\mathrm{x}$ \\
\hline Definition of key figure areas (strategic level) & $\mathrm{x}$ & $\mathrm{x}$ & $\mathrm{x}$ & $\mathrm{x}$ & $\mathrm{x}$ & $\mathrm{x}$ \\
\hline Review of the defined key figures & & $\mathrm{x}$ & $\mathrm{x}$ & $\mathrm{x}$ & & \\
\hline Breaking down of key figures & & & $\mathrm{x}$ & $\mathrm{x}$ & & \\
\hline Implementation / validation & $\mathrm{X}$ & $\mathrm{x}$ & $\mathrm{X}$ & $\mathrm{x}$ & $\mathrm{x}$ & $\mathrm{X}$ \\
\hline Adjustment of technological infrastructure & & $\mathrm{X}$ & & $\mathrm{X}$ & & \\
\hline Continuous improvement & & & $\mathrm{x}$ & $\mathrm{X}$ & $\mathrm{x}$ & $\mathrm{X}$ \\
\hline
\end{tabular}

Source: own literature analysis

Bourne et al. summarizes this procedure even more briefly in three steps: "It is proposed here that the development of performance measurement systems can be divided into three main phases. These are:

(1) the design of the performance measures.

(2) the implementation of the performance measures.

(3) the use of the performance measures. " (Bourne et al., 2000).

The goal of a future performance indicator system is derived from this, providing sustainable support for maximizing corporate success. Chalmeta formulates the result of this phase as follows: "The results of this analysis will make it possible to define the Critical Success Factors (CSF) that will allow its goals to be reached." (Chalmeta et al., 2012). If the change in a key figure value does not lead to a measure in the later course, the key figure system is not aligned closely enough to the corporate goals and is therefore less relevant for corporate management. Once the corporate goals have been clearly defined and known, the key figure areas need to be determined. Depending on the hierarchical structure of the company, it may make sense to involve employees right from the start. If a company has many hierarchical levels, it is advisable 
to use the defined key figure areas for the next levels, to break down further depending on the size of the company. (Kleindienst, 2017), (Chalmeta et al., 2012).

During implementation, the previously defined key figures are linked to one another, depending on the type of key figure system, and used together with the employees. The next step is to validate the implementation of the key figure system and to continuously improve it. According to Chalemeta (Chalmeta et al., 2012), it should be noted that the deployment of the indicators from the strategic to the tactical and operational level has been carried out properly. Bourne et al. (Bourne et al., 2000) notes on this last phase in addition that information and feedback from the measures should be used to challenge the assumptions and test the validity of the strategy. (In addition to the main design steps mentioned, other steps are also mentioned in the literature. These serve for further quality assurance of the main steps. Chalmeta et al., Möller et al. as well as Neely et al. include a planning phase in preparation at the beginning of the introduction of a key figure system. In addition to the planning phase, a phase to review the defined key figures is also scheduled before implementation and the breaking down of the key figures to lower company levels is explicitly shown. The supporting phase "alignment of technological infrastructure" also serves to safeguard the functionality of the framework. In this phase it is ensured, on the one hand, that the data for calculating the key figures are automatically provided and, on the other hand, the supporting IT systems are aligned with the company's goals. (Chalmeta et al., 2012), (Möller et al., 2015).

In addition to the pure conception, the key figure system created must meet other requirements. This includes the comprehensibility in the form of interpretation-free and comprehensible key figures as well as the balance regarding the scope of the investigation and the types of key figures. The use of standardized key figures is a further requirement and helps with a company or industry comparison. In general, care should be taken to design a key figure system as simply as possible, but as detailed as necessary. In addition to content-related requirements, the cost efficiency of the key figure system must be ensured when recording and evaluating the key figures. (Gladen, 2014), (Kleindienst, 2017).

\section{Results}

The literature research has shown that there are already EAM frameworks and models, such as the models from Zachmann (Zachman, 1987), TOGAF (The Open Group, 2020) or TUM (Technische Univerität München) (Matthes et al., EAM KPI Catalogue, 2011), which show how EAM supports the company. However, none of the models presented shows how the EAM added value affects the success of a company or can be calculated. Key figure systems (e.g. balanced scorecard) and key figures offer the possibility of quantifying and additionally visualizing the EAM added value achieved. To do this, the findings from this literature review on EAM, key figure systems and key figures must be combined with one another. 


\section{icalanme}

$4^{\text {th }}$ International Conference on Advanced Research in Amsterdam, Netherlands BUSINESS, MANAGEMENT \& ECONOMICS 16-18 July 2021

\section{Conclusions, proposals, recommendations}

1. Results on this review provide a first rough overview but must be adapted individually for each company.

2. In future research key figures and the corresponding value add will be collected to compile a generic "EAM Measurement Framework".

3. Further investigations should be done regarding the risk of not implementing EAM in organizations.

\section{References}

Alaloul et al., W. (2020). Industrial Revolution 4.0 in the construction industry: Challenges and opportunities for Stakeholders. Ain Shams Engineering Journal, Vol. 11., S. 225-230.

Becker, F. (2012). Zitat und Manuskript - erfolgreich recherchieren, richtig zitieren, Formal korrekt gestalten. Bilefeld: Schäffer-Poeschel Verlag.

Bente et al., S. (2012). Collaborative Enterprise Architecture. USA: Elsevier Inc.

Bernardis et al., A. (2017). Auf zu neuen Ufern. Harvard Business Manager: Agiles Management, April Ausgabe. Jg. 17, S. 6-12.

Bititci et al., U. (1997). Integrated performance measurement systems: A development guide. International Journal of Operations \& Production Management, Nr. 5. Jg. 17, S. 522-534.

Bitkom. (2011). Enterprise Architecture und Enterprise Architecture Management. In Bitkom, Enterprise Architecture Management-neue Disziplin für die ganzheitliche Unternehmensentwicklung (S. 11-15). Berlin: Bundesverband Informationswirtschaft,Telekommunikation und neue Medien e. V.

Bourne et al., M. (2000). Designing, implementing and updating performance measurement systems. International Journal of Operations \& Production Management, S. 754-771.

Brecht, U. (2012). BWL für Führungskräfte. Wiesbaden: Springer Gabler.

Brunner, J. (1999). Value-Based Performance Management: Wertsteigernde Unternehmensführung: Strategien - Instrumente - Praxisbeispiele. Wiesbaden: Springer.

Chalmeta et al., R. (2012). Methodology to develop a performance measurement system in small and medium-sized enterprises. International Journal of Computer Integrated Manufacturing, Vol. 25. No. 8, S. 716-740.

Disselkamp, M. (2012). Innovationsmanagement. Wiesbaden: Springer Gabler. 


\section{icalanme}

$4^{\text {th }}$ International Conference on Advanced Research in Amsterdam, Netherlands BUSINESS, MANAGEMENT \& ECONOMICS

\section{6-18 July 2021}

Distelzweig, A. (2014). Performance Measurement in der Beschaffung. Wiesbaden: Springer Gabler.

Durst, M. (2007). Werteorientiertes Management von IT-Architekturen. Wiesbaden: Deutscher Universitäts-Verlag.

Garengo, P. (2005). Performance measurement systems in SMEs: A review for a research agenda. International Journal of Management Reviews, Volume7, Issue 1, 25-47

Gladen, W. (2014). Performance Measurement. Wiesbaden: Springer Gabler.

Harrison, B. (1989). Framework 3 Das umfassende Anwenderbuch. Braunschweig: Vieweg.

Hierzer, R. (2017). Prozessoptimierung 4.0: den digitalen Wandel als Chance nutzen. Freiburg: Haufe-Lexware.

Keuntje et al. (2010). Enterprise Architecture Management in der Praxis. Düsseldorf: Symposion Publishing GmbH.

Kleindienst, B. (2017). Performance Measurement und Management. Wiesbaden: Springer Gabler.

Kluge, C. (2006). How to realise corporative value from enterprise architecture. Goteborg: IT University of Goteborg.

Kornmeier, M. (2018). Wissenschaftlich schreiben leicht gemacht. Bern: Haupt Verlag.

Langenberg et al, K. (2004). Enterprise architecture: What aspects is current research targeting? EPFL Technical Report IC/2004, S. 77.

Mathur et al., A. (2011). Performance measurement in automated manufacturing. Measuring Business Excellence. Vol. 15, No. 1.

Matthes et al., F. (2005). Enterprise Architecture Management Tool Survey 2005. Von https://wwwmatthes.in.tum.de/pages/k1qtzwl1a4hm/Enterprise-ArchitectureManagement-Tool-Survey-2005 abgerufen am 25.01.2021.

Matthes et al., F. (2011). EAM KPI Catalog. München: Technische Hochschule München.

Minciu et al., M. (2020). New decision systems in the VUCA world. Management \& Marketing. Challenges for the Knowledge Society, Vol. 15, No. 2., S. 236-254.

Möller et al., K. (2015) Performance Management - Konzept, Erfahrungen und Ausgestaltung einer neuen Disziplin. Contolling, Jg. 27, Nr. 2, S. 74-80. 


\section{icalanme}

$4^{\text {th }}$ International Conference on Advanced Research in Amsterdam, Netherlands BUSINESS, MANAGEMENT \& ECONOMICS

Neely et al., A. (1995). Performance measurement system design. International Journal of Operations \& Production Management, Jg. 15, Nr. 4., S. 80-116.

Neely et al., A. (2002). Getting the measure of your business. Cambridge: Cambridge University Press .

Nienhüser et al., W. (2003). Die wissenschaftliche Bearbeitung personalwirtschaftlicher Problemstellungen. Eine Einführung. Essen, Deutschland. Essener Beiträge zur Personalforschung. Essen: Lehrstuhl für Allgemeine Betriebswirtschaftslehre.

Ossola-Haring et al., C. (2016). 11 irrtümer über Kennzahlen. Wiesbaden: Springer Gabler.

Richert, J. (2006). Performance Measurement in Supply Chains. Wiesbaden: Gabler.

Rico, G. (2002). Garantiert schreiben lernen. Hamburg: Rowohlt-Taschenbuch-Verlag.

Siepermann et al., M. (19.02.2018). Enterprise Architecture. Von Gabler Wirtschaftslexikon: https://wirtschaftslexikon.gabler.de/definition/enterprise-architecture-54012/version277071 abgerufen am 25.01.2021.

Tannady et al., H. (2020). Enterprise Architecture Artifacts Enablers for IT Strategy and Business Alignment in Forwarding Services. International Journal of Advandes Trends in Computer Science and engineering, Vol. 9, No. 2., S. 1465-1472.

The Open Group. (2018). The TOGAF Standard, Version 9.2. Van Haren Publishing.

Weber, J. (1999). Einführung in das Controlling. Stuttgart: Schäffer/Pöschel.

Wettstein, T. (2001). Gesamtheitliches Performance Measurement: Vorgehensmodell und informationstechnische Ausgestaltung. In B. Britzelmaier et al, Inforamtionsmanagement - Herausforderungen und Perspektiven (S. 229-239). Stuttgart/leipzig/Wiesbaden: Teubner.

Zachman, J. (1987). A framework for information systems architecture. IBM Systems Journal. Vol. 26, No. 3, S. S. 277-293. 